\title{
Metode Regresi yang Tepat Untuk Meramalkan Permintaan Minyak Solar di Kabupaten Sumbawa
}

\author{
Koko Hermanto ${ }^{1}$, Fidya Rizqika ${ }^{2}$ \\ ${ }^{1}$ Universitas Teknologi Sumbawa,kokoaction88@gmail.com \\ ${ }^{2}$ Universitas Teknologi Sumbawa, Frizqika@gmail.com
}

\begin{abstract}
This study aims to find the proper regression method to predict the amount of demand for fuel oil in the form of diesel fuel in Sumbawa Regency. The data needed for this research are data on the amount of monthly diesel oil demand in 2018. The data were analyzed by various regression methods to predict the number of requests as the dependent variable $(Y)$ influenced by the month of demand as a independent variable $(x)$. The four methods chosen for analysis are linear, quadratic, cubic, exponential and logarithmic regression. The selection of the proper regression method predicts the case in this study based on the coefficient of determination $\left(R^{2}\right)$ and the data processing using SPSS. The results of the study show that the right method for forecasting diesel oil demand in 2019 is to use cubic regression methods.
\end{abstract}

Keywords: Forecasting, Regression Method, Determinant Coefficient, Solar Oil.

\begin{abstract}
Abstrak. Penelitian ini bertujuan untuk menentukan metode regresi yang tepat untuk meramalkan jumlah permintaan bahan bakar minyak (BBM) berupa solar di Kabupaten Sumbawa. Data yang diperlukan untuk penelitian ini adalah data jumlah permintaan minyak solar perbulan pada tahun 2018. Data tersebut dianalisis dengan berbagai metode regresi untuk meramalkan jumlah permintaan sebagai variabel terikat $(Y)$ dipengaruhi oleh bulan permintaan sebagai varibel bebas $(x)$. Empat metode yang dipilih untuk dianalisis adalah regresi linier, kuadratik, kubik, eksponensial dan logaritmik. Pemilihan metode regresi yang tepat meramalkan kasus pada penelitian ini berdasarkan nilai koefisien determinasi $\left(R^{2}\right)$ dan pengolahan datanya menggunakan SPSS. Hasil penelitian menunjukkan bahwa metode yang tepat untuk meramalkan permintaan minyak solar pada tahun 2019 adalah dengan menggunakan metode regresi kubik.
\end{abstract}

Keywords: Peramalan, Metode Regresi, Koefisien determinan,Minyak Solar.

\section{Pendahuluan}

Perusahan yang baik tentu memiliki tujuan jangka panjang supaya pada masa yang akan datang dapat mengalami perubahan yang baik. Permasalahan yang umum dihadapi oleh para pemilik perusahaan adalah bagaimana meramalkan permintaan, pendapatan atau penjualan barang dan jasa di masa yang akan datang berdasarkan data yang telah dimiliki sebelumnya. hasil peramalan tersebut sangat berpengaruh pada keputusan pemilik perusahaan untuk menentukan jumlah barang yang harus disediakan oleh perusahaan, apabila memesan barang dalam jumlah yang cukup banyak dan ternyata penjualan barang tersebut hanya terjual beberapa saja. Perencanaan yang efektif baik untuk jangka panjang maupun jangka pendek bergantung pada peramalan permintaan untuk produk perusahaan. Apabila peramalan atau prediksi ini diterapkan dalam bagian proses perencanaan 
produksi maka pihak perusahaan akan lebih terbantu dalam penjadwalan produksi, karena prediksi ini dapat memberikan output terbaik sehingga diharapkan resiko kesalahan yang disebabkan oleh kesalahan perencanaan dapat ditekan seminimal mungkin [1].

Kegiatan peramalan merupakan suatu duagaan atau prakiraan terhadap permintaanuntukmasa yang akan datang, selain itu hasil prediksi peramalan yang digunakan untuk perencanaan dan penyusunan kegiatan di masa yang akan datang dapat juga dilakukan dengan menggunakan data lampau, dimana data lampau tersebut akan dilakukan sebuah analisa ilmiah, yaitu dengan menggunakan metode statistika.

Berdasarkan permasalan yang dipaparkan di atas peneliti melakukan analisa dalam menentukan metode regresi yang tepat untuk meramalkan jumlah permintaan minyak solar di Kabupaten Sumbawa pada tahun 2019, metode koefisien determinan salah satu metode yang digunakan untuk mengambil keputusan penentuan metode regresi yang tepat untuk meramalkan permintaan. Sehingga dari hasil penelitian ini dapat menjadi bahan pertimbangan bagi PT Pertamina Terminal Bahan Bakar Minyak (TBBM) Labuan Badas untuk menyediakan persediaan minyak solar untuk konsumen di Kabuten Sumbawa. PT Pertamina TBBM Badas merupakan salah satu Terminal BBM yang melayani dan mendistribusikan BBM kepada konsumen di Kabupaten Sumbawa dan Kabupaten Sumbawa Barat serta BBK (Pertamax \& Pertalite) untuk Pulau Sumbawa. Terletak di Jalan Raya Garuda Km. 08 Jurusan Pelabuhan Badas, Kabupaten Sumbawa, Provinsi Nusa Tenggara Barat. Dibangun pada Tahun 1979 diresmikan oleh Bapak Soeharto, dan mulai Beroperasi Tahun 1981. Luas Area $+41,300 \mathrm{~m}^{2}$. Perusahaan ini juga mengoperasikan 7 kilang minyak.

\section{Tinjauan Pustaka}

Menurut Heizen-Render peramalan permintaan adalah proyeksi permintaan untuk produk atau jasa perusahaan. Peramalan permintaan ini akan mempengaruhi perencanaan perusahaan akan produksi dan kapasitas perusahaan, sistem penjadwalan, serta sebagai input dalam perencanaan keuangan, pemasaran, dan kebutuhan sumberdaya manusia [2].

Peramalan dapat memberikan gambaran masa yang akan datang dengan akurat, dan sebagai pendorong semua aktivitas perencanaan. Alasan-alasan lain perusahaan melakukan peramalan adalah:

a. meningkatkan kepuasan konsumen;

b. mengurangi kekurangan persediaan;

c. kebutuhan persediaan pengaman yang lebih sedikit;

d. pengiriman yang lebih baik.

Seringkali kita mengalami kesulitan dalam menentukan metode peramalan seperti apa yang sebaiknya diterapkan terhadap data yang kita miliki. Menentukan metode peramalan yang tepat,memang tidaklah mudah. Yang harus diingat dalam melakukan peramalan adalah bahwa tidak ada satu metode peramalan yang paling sempurna atau tidak ada satu metode peramalan terbaik yang dapat dipakai untuk semua jenis data yang kita miliki. Sebelum kita melakukan peramalan, hal yang penting yang harus kita lakukan adalah melihat pola data yeng kita miliki. 
Metode yang digunakan untuk membuat peramalan berbeda-beda tergantung periode peramalan yang akan ditentukan yaitu jangka sangat pendek, pendek, menengah,dan panjang. Perbedaan jangka waktu peramalan juga menunjukkan perbedaan jumlah kebutuhan data yang harus tersedia. Semakin panjang jangka waktu peramalannya semakin banyak jumlah data yang di butuhkan. Pada penelitian ini metode peramalan yang di gunakan adalah metode regresi.

Beberapa metode regresi yang digunakan dalam peramalan adalah sebagai berikut [3]:
a. Regresi Linier
$\hat{Y}=a+b X$
b. Kuadratik
$\hat{Y}=a+b X^{2}$
c. Kubik
$\widehat{Y}=a+b X^{2}+c X^{3}$
d. Eksponensial
$\widehat{Y}=a\left(e^{b x}\right)$
e. Logistik
$\hat{Y}=\frac{1}{a b^{x}}$
f. Grownth
$\hat{Y}=e^{a+b x}$
g. Compound
$\hat{Y}=a b^{x}$

Pemilihan metode regresi yang tepat dalam meramalkan dapat dilakukan dengan menggunakan beberapa metode, yaitu [3]:

a. Nilai Sidik Ragam (F-Test)

$$
\mathrm{F}-\text { test }=\frac{\text { Kuadrat Tengah Regresi }}{\text { Kuadrat Tengah Galat }}
$$

Metode regresi yang dipilih dari metode ini adalah metode regresi yang menghasilkan nilai F-Test bermakna dengan nilai terbesar.

b. Koefisien determinasi $\left(R^{2}\right)$

$$
R^{2}=\frac{\text { Jumlah Kuadrat Regresi }}{\text { Jumlah Kuadrat Total }} \times 100 \%
$$

Metode regeresi yang dipilih dari metode ini adalah metode regresi yang menghasilkan nilai $R^{2}$ terbesar (mendekati $100 \%$ )

c. Kuadrat Tengah Galat (mean Square Error (MSE))

$$
\text { MSE }=\frac{\text { Jumlah Kuadrat Galat }}{\text { Derajat Bebas Galat }}
$$

Metode regresi yang dipilih dari metode ini adalah metode regresi yang mempunyai nilai MSE paling kecil.

d. Persentase Galat (Percentage Error (PE))

$$
\mathrm{PE}=\frac{\text { Nilai Galat }}{\text { Nilai Pengamatan }} \times 100 \%
$$

Nilai yang negative akan dimutlakan untuk mencari rata-rata PE. Metode regresi yang dipilih adalah metode regresi yang mempunyai nilai PE terkecil. 
Dari ke tujuh metode regresi tersebut pada penelitian ini akan diuji empat metode regresi saja yaitu metode regresi linier, metode regresi kuadratik dan metode regresi kubik, sedangkan empat metode untuk menentukan metode peramalan regresi yang tepat pada penelitian ini akan menggunakan metode Koefisien determinasi $\left(R^{2}\right)$ sebagai metode untuk menentukan metode regresi yang tepat untuk peramalan permintaan minyak solar di Kabupaten Sumbawa. Perhitungan dilakukan dengan menggunakan bantuan paket program statistic yaitu SPSS untuk meningkatkan akurasi.

\section{Metodologi Penelitian}

\subsection{Data dan Populasi}

Adapun data penelitian yang diperlukan guna meramalkan permintaan minyak solar di Kabupaten Sumbawa dan Kabupaten Sumbawa Barat pada tahun 2019 terdiri dari data skunder yaitu data jumlah permintaan minyak solar pada tahun 2018 dalam satuan kilo liter (kl). Data jumlah permintaan minyak solar tesebut diperoleh dari PT. Pertamina TBBM Labuan Badas Kabupaten Sumbawa Provinsi Nusa Tenggara Barat. Data yang diperoleh berupa data permintaan harian selanjutnya data tersebut diolah menjadi data bulanan, Data permintaan minyak solar di Kabupaten Sumbawa tahun 2018 disajikan pada tabel 1.

Tabel 1. Jumlah Permintaan minyak Tahun 2018 di PT. Pertamina TBBM Badas

\begin{tabular}{clc}
\hline No. & Bulan & Jumlah Permintaan (kl) \\
\hline 1 & Januari & 3.520 \\
2 & Februari & 3.166 \\
3 & Maret & 4.736 \\
4 & April & 5.096 \\
5 & Mei & 5.784 \\
6 & Juni & 6.188 \\
7 & Juli & 5.694 \\
8 & Agustus & 5.608 \\
9 & September & 5.204 \\
10 & Oktober & 5.706 \\
11 & November & 5.397 \\
12 & Desember & 5.592 \\
\hline
\end{tabular}

Sumber: PT Pertamina TBBM Badas telah dihitung

\subsection{Definisi Variabel}

1. Variabel Devenden $(\hat{Y})$ $\hat{Y}=$ jumlah permintaan minyak solar

Jumlah permintaan minyak solar yang dimaksud adalah di Kabupaten Sumbawa dan Sumbawa Barat pada tahun 2018 dengan satuan kilo liter

2. Variabel Independen $(X)$

$X=$ variabel bulan

Periode bulan pada penelitian ini adalah Januari, Februari, Maret, April, Mei, Juni, Juli, Agustus, September, Oktober, November dan Desember. 


\subsection{Langkah-langkah Penelitian}

Adapun langkah-langkah penelitian ini dapat dilihat pada Gambar 1.

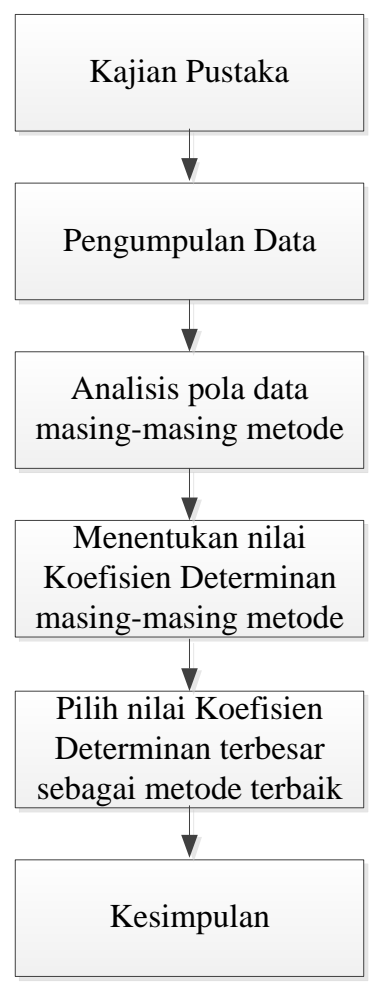

Gambar 1. Diagram alir penelitian

\section{Hasil dan Pembahasan}

Berdasarkan definisi variabel yang telah ditentukan sebelumnya maka Tabel 1 dapat dirbuah ke tabel 2 sebagai berikut.

Tabel 2. Jumlah Permintaan minyak Tahun 2018 di PT. Pertamina TBBM Badas

\begin{tabular}{lcc}
\hline \multicolumn{1}{c}{ Bulan } & X & Y \\
\hline Januari & 1 & 3.520 \\
Februari & 2 & 3.166 \\
Maret & 3 & 4.736 \\
April & 4 & 5.096 \\
Mei & 5 & 5.784 \\
Juni & 6 & 6.188 \\
Juli & 7 & 5.694 \\
Agustus & 8 & 5.608 \\
September & 9 & 5.204 \\
Oktober & 10 & 5.706 \\
November & 11 & 5.397 \\
Desember & 12 & 5.592 \\
\hline
\end{tabular}

Sumber: PT Pertamina TBBM Badas telah dihitung 
Data Tabel 2 yaitu data pada kolom X dan Y di input ke SPSS, selanjutnya digambar model grafik scatter plot permintaan minyak solar periode tahun 2018 dengan SPSS yaitu memilih menu Graphs $\rightarrow$ Legacy Dialogs $\rightarrow$ Scatter $\rightarrow$ Simple Scatterplot pada menu Simple Scatterplot input "jumlah permintaan" sebagai $Y$ Axis dan "bulan" sebagai $X$ Axis kemudian pilih OK maka outputnya berupa grafik yang disajikan pada Gambar 2. Dari gambar grafik ini dapat memberikan informasi berupa gambaran pola data permintaan minyak solar pada periode tahun 2018.

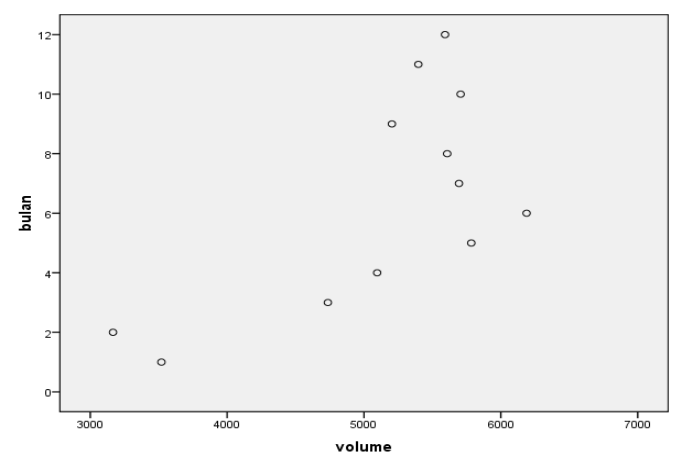

Gambar 2. Grafik Jumlah Permintaan Minyak Solar

Berdasarkan data Tabel 1 dan Gambar 2 jika peramalan didekati dengan menggunakan metode regresi linier maka double klik pada gambar grafik kemudian pilih menu $\bar{\longleftarrow}$ atau Add Fit Line at Total kemudian pilih liniear sehingaa model output grafiknya disajikan pada Gambar 3.

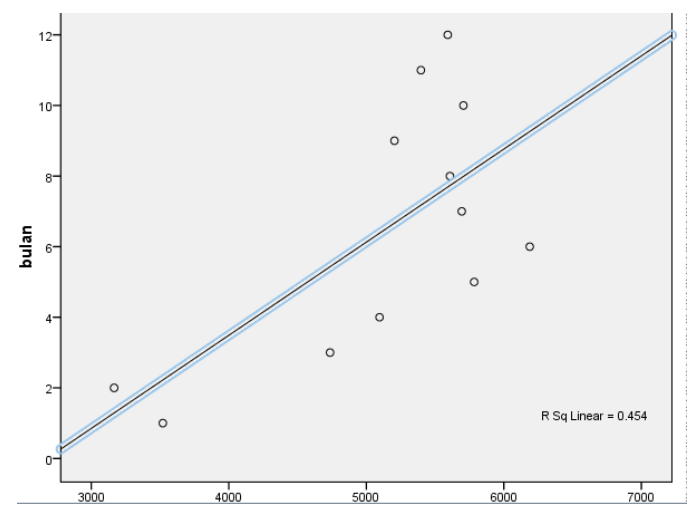

Gambar 3. Grafik Jumlah Permintaan menggunaka Regresi Linier

Berdasarkan data Tabel 1 jika peramalan didekati dengan menggunakan metode regresi kuadratik maka model grafiknya disajikan pada Gambar 5. Adapun langkah-langkah menampilin grafiknya sama dengan menyajikan grafik linier sebelumnya tetapi klik menu Quadratic. 


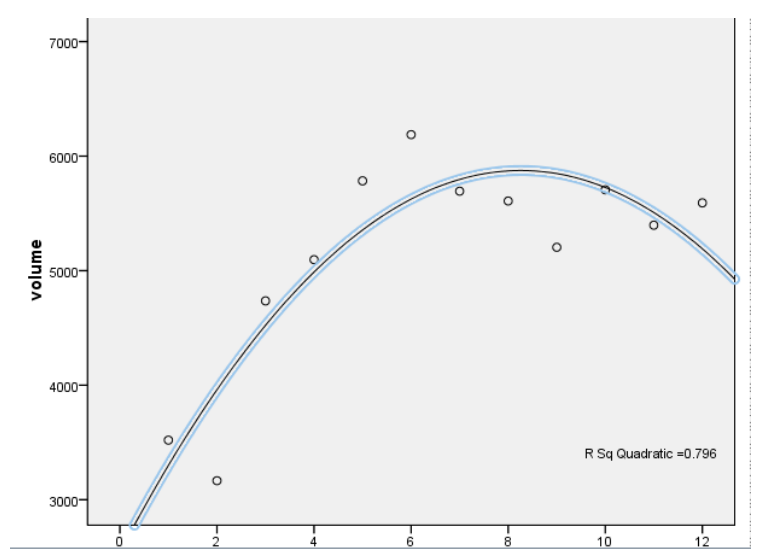

Gambar 4. Grafik Jumlah Permintaan menggunaka Regresi Kuadratik

Berdasarkan data Tabel 1 jika peramalan didekati dengan menggunakan metode regresi kubik maka model grafiknya disajikan pada Gambar 5. Adapun langkah-langkah menampilin grafiknya sama dengan menyajikan grafik linier sebelumnya tetapi klik menu Cubic.

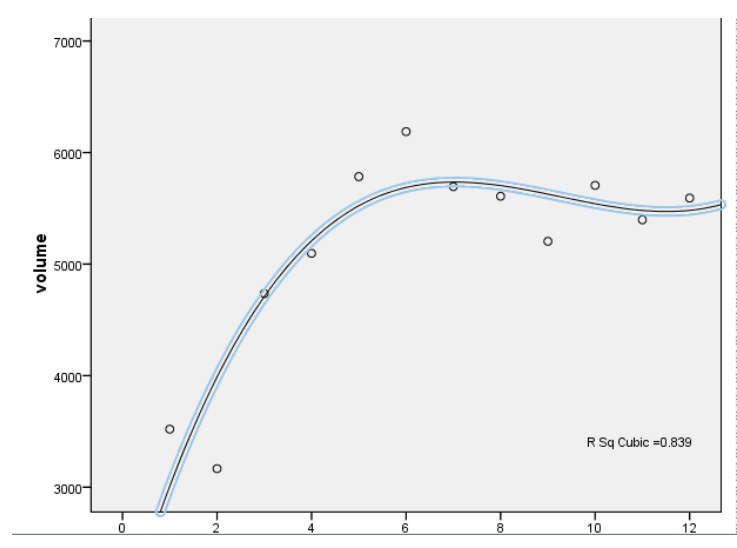

Gambar 5. Grafik Jumlah Permintaan menggunaka Regresi Kubik

Dari Gambar 3 sampai Gambar 5 terlihat pola data lebih cocok menggunakan metode Regresi Kubik. Untuk lebih meyakinkan jawaban tersebut maka selanjutnya akan ditentukan nilai koefisien determinasi $\left(R^{2}\right)$ ketiga metode tersebut. Perhitungan nilai koefisien determinan dilakukan dengan menggunakan SPSS sehingga diperoleh nilai $R^{2}$ untuk masing-masing metode disajikan pada Tabel 2 berikut.

Tabel 2. Nilai Koefisien Determinan masing-masing metode

\begin{tabular}{|c|c|c|c|c|c|c|c|c|c|}
\hline \multirow[b]{2}{*}{ Equation } & \multicolumn{5}{|c|}{ Model Summary } & \multicolumn{4}{|c|}{ Parameter Estimates } \\
\hline & R Square & $\mathrm{F}$ & df1 & $\mathrm{df} 2$ & Sig. & Constant & b1 & b2 & b3 \\
\hline Linear & .454 & 8.304 & 1 & 10 & .016 & 4.023E3 & 171.955 & & \\
\hline Quadratic & .796 & 17.520 & 2 & 9 & .001 & $2.541 \mathrm{E} 3$ & 807.218 & -48.866 & \\
\hline Cubic & .839 & 13.858 & 3 & 8 & .002 & $1.738 \mathrm{E} 3$ & $1.428 \mathrm{E} 3$ & -163.551 & $\begin{array}{r}5.88 \\
1\end{array}$ \\
\hline
\end{tabular}


Nilai koefisien determinan atau R Square mengukur kekuatan hubungan antara nilai variabel dependent sebenarnya dan nilai variabel dependent yang diprediksi model. Dari Tabel 2 nilai R Square untuk metode Regresi liniear sebesar 0,454. Hal ini menjelaskan bahwa presentase sumbangan pengaruh variabel independen yaitu variabel bulan permintaan $(X)$ dan jumlah permintaan solar variabel dependen $(Y)$ yaitu sebesar 0,454 sedangkan sisanya 0,546 di pengaruhi oleh variabel yang lain yang tidak di masukkan dalam model penelitian. Nilai R Square untuk metode Quadratic sebesar 0,796. Hal ini menjelaskan bahwa presentase sumbangan pengaruh variabel independen yaitu variabel bulan permintaan $(X)$ dan jumlah permintaan solar variabel dependen $(Y)$ yaitu sebesar 0,796 sedangkan sisanya 0,204 di pengaruhi oleh variabel yang lain yang tidak di masukkan dalam model penelitian. Sedangkan untuk R Square untuk metode cubic sebesar 0,839. hal ini menjelaskan bahwa presentase sumbangan pengaruh variabel independen yaitu variabel bulan permintaan $(X)$ dan jumlah permintaan solar variabel dependen $(Y)$ yaitu sebesar 0,454 sedangkan sisanya 0,161 di pengaruhi oleh variabel yang lain yang tidak di masukkan dalam model penelitian. Karena metode Regresi Cubic memiliki nilai paling besar maka metode peramalan yang tepat untuk meramalkan permintaan minyak solar untuk tahun berikutnya.

\section{Kesimpulan}

Berdasarkan hasil yang diperoleh, bahwa di antara ketiga metode yang digunakan untuk meramalkan jumlah permintaan minyak solar di Kabupaten Sumbawa dipilih metode Regresi Cubic sebagai metode peramalan yang paling tepat untuk meramalkan jumlah permintaan minyak solar di Kabupaten Sumbawa.

\section{Ucapan Terimakasih}

Pada kesempatan ini tim peneliti menyampaikan terima kasih kepada PT Pertamina TBBM Labuan Badas Kabupaten Sumbawa yang telah memberikan ijin untuk melakukan penelitian. Semoga penelitian ini dapat bermanfaat.

\section{Daftar Pustaka}

[1] Fiati, Rina, 2009, Aplikasi Sistem Pendukung Keputusan PeramalanPenjualan Barang, Staf Pengajar Fakultas Teknik Universitas Muria Kudus.

[2] Hibatul Khiram. 2017. Analisis Perencanaan Sistem Distribusi Pada PT. Lafarge Cement Indonesia Aceh Besar. 2 (1): 118-134.

[3] Rudi Hartono. 2011. Model Regresi yang tepat untuk menggambarkan Produksi Total Bakteri Asam Laktat (BAL) Sosis Probiotik Berdasarkan Lama Penyimpanan. 29 (1): 32-38.

[4] Sulistyono. 2017. Peramalan Produksi dengan Metode Regresi Linier Berganda. Prozima. 1 (2): 82-89. 